\title{
Prenatal Diagnosis of Galen Vein Aneurysm Using Ultrasonography and Magnetic Resonance Imaging and Perinatal and Long- Term Neurological Outcomes: A Case Series
}

\section{Diagnóstico do aneurisma de veia de Galeno por meio de ultrassonografia e ressonância magnética e resultados perinatais e neurológicos: série de casos}

Pedro Pires ${ }^{1}$ Larisse de Brito Aurélio Martins ${ }^{2}$ Norma Maria Tenório Brito Pires ${ }^{2}$ Heron Werner ${ }^{3}$ Adilson Cunha Ferreira ${ }^{4}$ Edward Araujo Júnior ${ }^{5}$

\footnotetext{
${ }^{1}$ Department of Obstetrics and Gynecology, Universidade de Pernambuco, Recife, PE, Brazil

2 Real Hospital Português de Beneficência em Pernambuco, Recife, PE, Brazil

${ }^{3}$ Clínica de Diagnóstico por Imagem, Rio de Janeiro, RJ, Brazil

${ }^{4}$ Faculdade de Medicina de São José do Rio Preto, São José do Rio Preto, SP, Brazil

${ }^{5}$ Department of Obstetrics, Escola Paulista de Medicina, Universidade Federal de São Paulo, São Paulo, SP, Brazil
}

Rev Bras Ginecol Obstet 2017;39:309-314.

\begin{abstract}
Address for correspondence Edward Araujo Júnior, PhD, Department of Obstetrics, Escola Paulista de Medicina, Universidade Federal de São Paulo, Rua Belchior de Azevedo, 156, apto. 111, Torre Vitória, São Paulo, SP, Brazil (e-mail: araujojred@terra.com.br).
\end{abstract}

\begin{abstract}
Keywords

- Galen vein aneurysm

- prenatal diagnosis

- ultrasonography

- magnetic resonance

- perinatal outcomes
\end{abstract}

Objective To describe the prenatal diagnosis of Galen vein aneurysm (GVA) based on ultrasonography and magnetic resonance imaging (MRI) in a series of cases, as well as its postnatal outcomes and follow-up until 4 years of age.

Methods A retrospective longitudinal study was performed, analyzing a database comprising seven cases of prenatal diagnosis of GVA at two Brazilian institutions from February of 2000 to May of 2012. The following data were evaluated: gestational age at diagnosis, GVA dimensions on ultrasonography, associated fetal changes, findings on fetal echocardiography, gestational age at delivery, type of delivery, birth weight, Apgar score at the 1st and 5th minutes, neonatal outcomes, and survival with follow-up until 4 years of age.

Results The mean gestational age \pm standard deviation on the prenatal diagnosis of GVA based on ultrasonography was $25 \pm 4.9$ weeks. The mean length of GVA was $3.2 \pm$ $0.4 \mathrm{~cm}$. The mean gestational age at birth was $37.5 \pm 0.7$ weeks, and a cesarean section was performed in $85.7 \%$ of the cases (6/7). The mean birth weight was $3,070 \pm 240.4 \mathrm{~g}$. The total survival rate was $42.8 \%(4 / 7)$, with three neonatal deaths. Of the four survivors, three presented with normal neuropsychomotor development until 4 years received

September 27, 2016 accepted after revision January 11, 2017 published online April 26, 2017
DOI https://doi.org/ 10.1055/s-0037-1601401. ISSN 0100-7203.
Copyright $(2017$ by Thieme Revinter

Publicações Ltda, Rio de Janeiro, Brazil
License terms

(c) $(1) \$$ 


\section{Resumo}

\author{
Palavras-chave \\ - Aneurisma da veia de \\ Galeno \\ - Diagnóstico pré-natal \\ - Ultrassonografia \\ - Ressonância \\ magnética \\ - Resultados perinatais
}

of age and only one showed serious neurological sequelae. Ultrasonography and MRI showed similar findings for all seven cases.

Conclusions Galen Vein Aneurysm is associated with a high neonatal death rate. Therefore, its prenatal diagnosis is essential for parent counseling and follow-up at tertiary care institutions.

Objetivo Descrever o diagnóstico pré-natal de uma série de casos de aneurisma de veia de Galeno (AVG) por meio de ultrassonografia e ressonância magnética (RM), bem como os resultados pós-natais e acompanhamento até 4 anos de vida.

Métodos Realizou-se um estudo retrospectivo longitudinal com análise de banco de dados de sete casos de diagnóstico pré-natal de AVG em dois serviços brasileiros entre fevereiro de 2000 e maio de 2012. Foram avaliados a idade gestacional ao diagnóstico, dimensões do AVG na ultrassonografia, alterações fetais associadas, achados da ecocardiografia fetal, idade gestacional ao parto, tipo de parto, peso ao nascimento, índice de Apgar no $1^{\circ}$ e $5^{\circ}$ minutos, resultados neonatais, e sobrevida com acompanhamento até 4 anos de idade.

Resultados $A$ idade gestacional média \pm desvio-padrão ao diagnóstico pré-natal do AVG pela ultrassonografia foi de $25 \pm 4,9$ semanas. O comprimento médio do AVG foi $3,2 \pm 0,4 \mathrm{~cm}$. A idade gestacional média ao nascimento foi $37,5 \pm 0,7$ semanas, sendo que, em $85,7 \%$ dos casos (6/7) o parto foi cesáreo. O peso médio ao nascimento foi de $3.070 \pm 240,4$ gramas. A sobrevida total foi de $42,8 \%$ (4/7), com três óbitos neonatais. Dos quatro sobreviventes, três apresentaram desenvolvimento neuropsicomotor normal até a idade de 4 anos, sendo que apenas um apresentou sequelas neurológicas graves. Ultrassonografia e RM apresentaram achados semelhantes nos sete casos. Conclusões O AVG está associado à elevada taxa de óbito neonatal, sendo, portanto, fundamental o seu diagnóstico pré-natal precoce para aconselhamento dos pais e seguimento em serviço terciário.

\section{Introduction}

Galen vein aneurysm (GVA) is a rare congenital malformation arising because of the presence of multiple arteriovenous shunts that drain to a median prosencephalic vein. ${ }^{1}$ There is usually only a single malformation corresponding to $\sim 1 \%$ of all vascular cerebral malformations. However, it may be associated with congenital heart disease, hydrops, and cystic hygroma. ${ }^{2}$ Its etiology is unknown, and there is no described familial inheritance. Heart failure is the most common symptom in the neonatal period, but seizures and other neurological signs may also be observed. ${ }^{3,4}$

Because GVA has a low incidence rate but high morbidity and mortality rates, a prenatal diagnosis is necessary for adequate follow-up, delivery, and parent counseling. In general, the condition is prenatally diagnosed based on conventional ultrasonography when a cystic image that confirms dilation of the vein, located either in the middle region or slightly deviated from the central region, below the third ventricle on the middle supratentorial line is identified. ${ }^{5}$ Color Doppler imaging shows a turbulent flow inside the cyst, which may be associated with secondary ventriculomegaly. ${ }^{6}$ Magnetic resonance imaging (MRI) helps to confirm the diagnosis and also reveals complications such as hemorrhagic injury in the white matter of the brain. ${ }^{7}$ Other prenatal diagnostic methods such as ultrasonography in the 3-dimensional power Doppler mode have been described, but these have shown no advantages over conventional ultrasonography and MRI. ${ }^{8,9}$ Fetal echocardiography may help detect early signs of heart failure, which, together with hydrops, is the most common consequence of GVA.

Here we present a series of seven cases of prenatal diagnosis of GVA with their main findings based on conventional ultrasonography and MRI as well as their postnatal outcomes.

\section{Methods}

A retrospective longitudinal study was performed, analyzing a database of seven cases of prenatal diagnosis of GVA from February of 2000 to May of 2012 at two Brazilian institutions: Centro Integrado de Saúde Amaury de Medeiros da Universidade de Pernambuco (UPE) and Clínica de Diagnóstico por Imagem (CDPI). This study was approved by the Committee on Ethics in Research of the Universidade de Pernambuco (UPE). Five cases were from UPE and 2 from CDPI.

The following data were evaluated: gestational age (in weeks) at diagnosis, GVA dimensions on ultrasonography, associated fetal changes, findings on fetal echocardiography, 
gestational age at delivery, type of delivery, birth weight, Apgar score at the 1 st and 5th minutes, neonatal outcomes, and survival with follow-up until 4 years of age. In addition, we have described the main findings based on color Doppler ultrasonography and MRI.

\section{Results}

The mean gestational age \pm standard deviation on prenatal diagnosis of GVA by ultrasonography was $25 \pm 4.9$ weeks. The mean length and width of the GVA on diagnosis were $3.2 \pm$ $0.4 \mathrm{~cm}$ and $2.2 \pm 1.6 \mathrm{~cm}$, respectively. The mean gestational age at birth was $37.5 \pm 0.7$ weeks, and a cesarean section was performed in $85.7 \%$ of cases (6/7). The average birth weight was $3,070 \pm 240.4 \mathrm{~g}$. Mean Apgar scores at the 1 st and 5 th minutes were $8.5 \pm 0.7$ and $9.5 \pm 0.7$, respectively. The overall survival rate was $42.8 \%$ (4/7), with three neonatal deaths. Of the four survivors, three presented with normal neuropsychomotor development until 4 years of age and only one showed serious neurological sequelae. - Table 1 presents the description of the pre- and postnatal data of the seven cases of GVA. - Fig. 1 shows the pre- and postnatal imaging findings of case \#7. - Table 2 presents the description of the main findings based on conventional color Doppler ultrasonography and MRI in the seven cases of the prenatal diagnosis of GVA.

\section{Discussion}

Here we present a series of cases of prenatal diagnosis of GVA based on ultrasonography at an average gestational age of
25 weeks; our diagnosis agrees with the findings reported in most publications. ${ }^{8-10}$ Magnetic resonance imaging is used to evaluate associated neurological findings that may be of prognostic value. In our case series, MRI showed no diagnostic advantages over ultrasonography. In a series of 18 cases of GVA, MRI identified 3 cases of neuronal migration abnormalities that had not been identified by ultrasonography. ${ }^{2}$

In our series, associated findings were present in $71 \%$ of the cases (5/7) and cardiomegaly was the most frequent finding. However, in only two cases, a therapeutic preterm delivery was performed owing to congestive heart failure in the fetus. The mean gestational age at delivery was 37.5 weeks, and the mean birth weight was adequate in terms of the gestational age. In a series of 21 cases, the mean gestational age at birth was high ( 38.7 weeks) and the mean birth weight was also adequate in terms of the gestational age (3096 g). ${ }^{2}$ The most frequent type of delivery in our case series was cesarean section (86\%), which is in accordance with the high incidence of this type of delivery in Brazil, both in public and private institutions, regardless of fetal malformations. $^{11}$

Associated anomaly is a proven factor of adverse perinatal outcome in cases of GVA and termination of the pregnancy is indicated in countries where this procedure is legal. ${ }^{2}$ Regarding the type of delivery, in the absence of fetal cardiac dysfunction and isolated GVA, normal delivery is the best choice. In the presence of fetal cardiac dysfunction and isolated/associated GVA, there is no consensus in the literature and the choice should be based on the gestational age and the neonatal intensive care.

Table 1 Prenatal outcomes of fetuses diagnosed with Galen vein aneurysm

\begin{tabular}{|c|c|c|c|c|c|c|c|}
\hline Case\# & 1 & 2 & 3 & 4 & 5 & 6 & 7 \\
\hline $\begin{array}{l}\text { GA at } \\
\text { diagnosis } \\
\text { (weeks) }\end{array}$ & 33 & 36 & $32 w k, 1 d$ & 35 & 30 & 24 & 26 \\
\hline $\begin{array}{l}\text { Associated } \\
\text { findings }\end{array}$ & $\begin{array}{l}\text { cardiomegaly, } \\
\text { slight pericardial } \\
\text { effusion }\end{array}$ & $\begin{array}{l}\text { polyhydramnion, } \\
\text { ventriculomegaly, } \\
\text { cardiomegaly, } \\
\text { cervical vascular } \\
\text { congestion }\end{array}$ & Polyhydramnion & $\begin{array}{l}\text { ventriculomegaly, } \\
\text { cardiomegaly, } \\
\text { cervical vascular } \\
\text { congestion }\end{array}$ & $\begin{array}{l}\text { ventriculomegaly, } \\
\text { pericardial effusion, } \\
\text { cardiomegaly, } \\
\text { cervical vascular } \\
\text { congestion }\end{array}$ & None & None \\
\hline Fetal echo. & cardiomegaly, & $\begin{array}{l}\text { pulmonary } \\
\text { hypertension, } \\
\text { heart failure }\end{array}$ & Normal & $\begin{array}{l}\text { cardiomegaly, } \\
\text { pericardial } \\
\text { effusion, } \\
\text { heart failure }\end{array}$ & $\begin{array}{l}\text { cardiomegaly, } \\
\text { tricuspid failure, } \\
\text { pericardial effusion }\end{array}$ & Normal & Normal \\
\hline $\begin{array}{l}\text { GVA } \\
(\mathrm{cm})\end{array}$ & $2.9 \times 1.1$ & $3.2 \times 1.8$ & $2.2 \times 1.8$ & $7.0 \times 2.5$ & $4.2 \times 2.5$ & $3.0 \times 2.3$ & $3.5 \times 3.4$ \\
\hline $\begin{array}{l}\text { Type of } \\
\text { delivery }\end{array}$ & Vaginal & Cesarean & Cesarean & Cesarean & Cesarean & Cesarean & Cesarean \\
\hline $\begin{array}{l}\text { GA at birth } \\
\text { (weeks) }\end{array}$ & 37 & 39 & 38 & $36 w k, 1 d$ & $34 w k, 4 d$ & 38 & 39 \\
\hline $\begin{array}{l}\text { Apgar score, } \\
1 \text { st \& 5th min }\end{array}$ & 8 and 9 & 3 and 6 & 7 and 9 & 5 and 4 & 6 and 4 & 8 and 9 & 9 and 10 \\
\hline $\begin{array}{l}\text { Birth weight } \\
(\mathrm{g})\end{array}$ & 2900 & 2940 & 3180 & 2980 & 2550 & 3060 & 3240 \\
\hline $\begin{array}{l}\text { Neonatal } \\
\text { outcome }\end{array}$ & $\begin{array}{l}\text { GVA embolization } \\
\text { at } 6 \mathrm{mth}\end{array}$ & $\begin{array}{l}\text { ICU, digoxin, } \\
\text { furosemide }\end{array}$ & $\begin{array}{l}\text { discharge 4d } \\
\text { after birth }\end{array}$ & ICU for $28 \mathrm{~d}$ & heart failure & $3 w k$ in the ICU & $\begin{array}{l}\text { seizures, } \\
\text { hydrocephalus, } \\
\text { heart failure } \\
2 \text { wk after birth }\end{array}$ \\
\hline $\begin{array}{l}\text { Survival up } \\
\text { to } 4 \mathrm{yr} \text { of age }\end{array}$ & Normal & death at $48 \mathrm{~h}$ & $\begin{array}{l}\text { spontaneous } \\
\text { thrombosis at } 4 \mathrm{yr}, \\
\text { normal development }\end{array}$ & $\begin{array}{l}\text { serious neurologic } \\
\text { sequelae }\end{array}$ & death on 4th day & $\begin{array}{l}\text { death during } \\
\text { surgery }\end{array}$ & Normal \\
\hline
\end{tabular}

Abbreviations: d, day(s); echo., echocardiography; GA, gestational age; GVA, Galen vein aneurysm; ICU, intensive care unit; mth, month(s); wk, week(s); yr, year(s). 


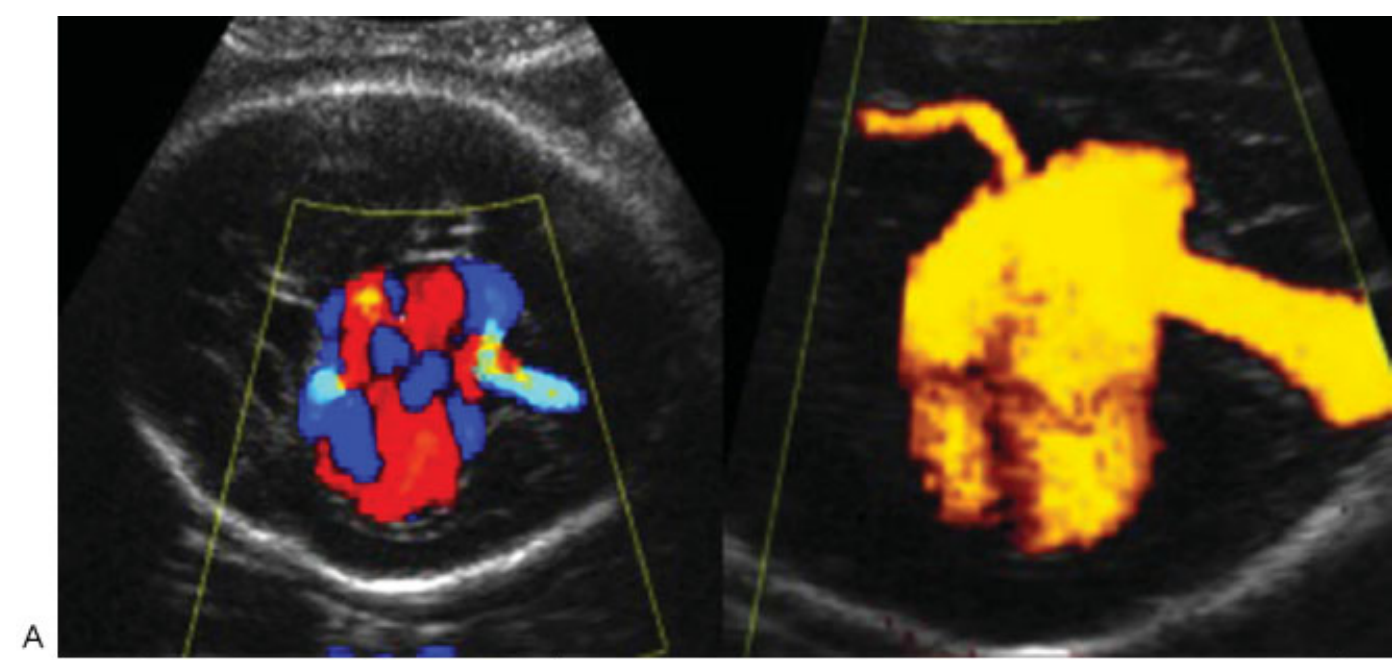

A

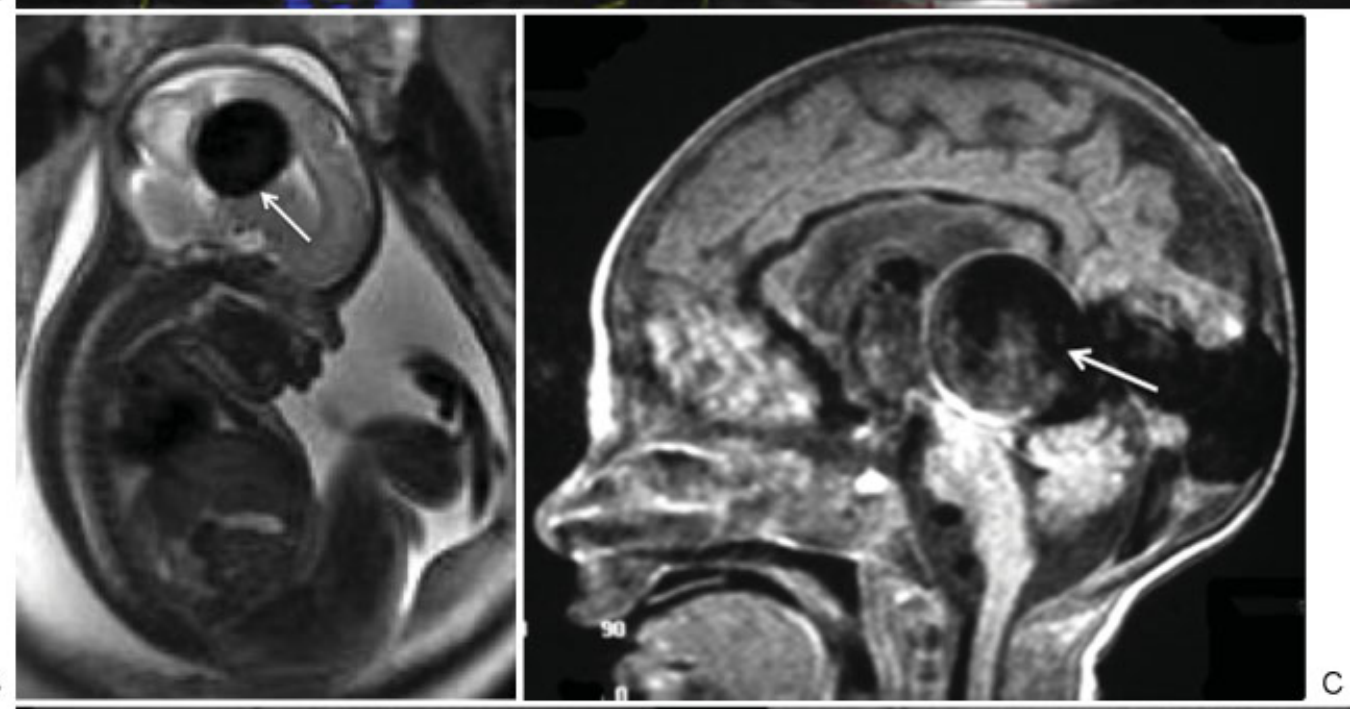

B

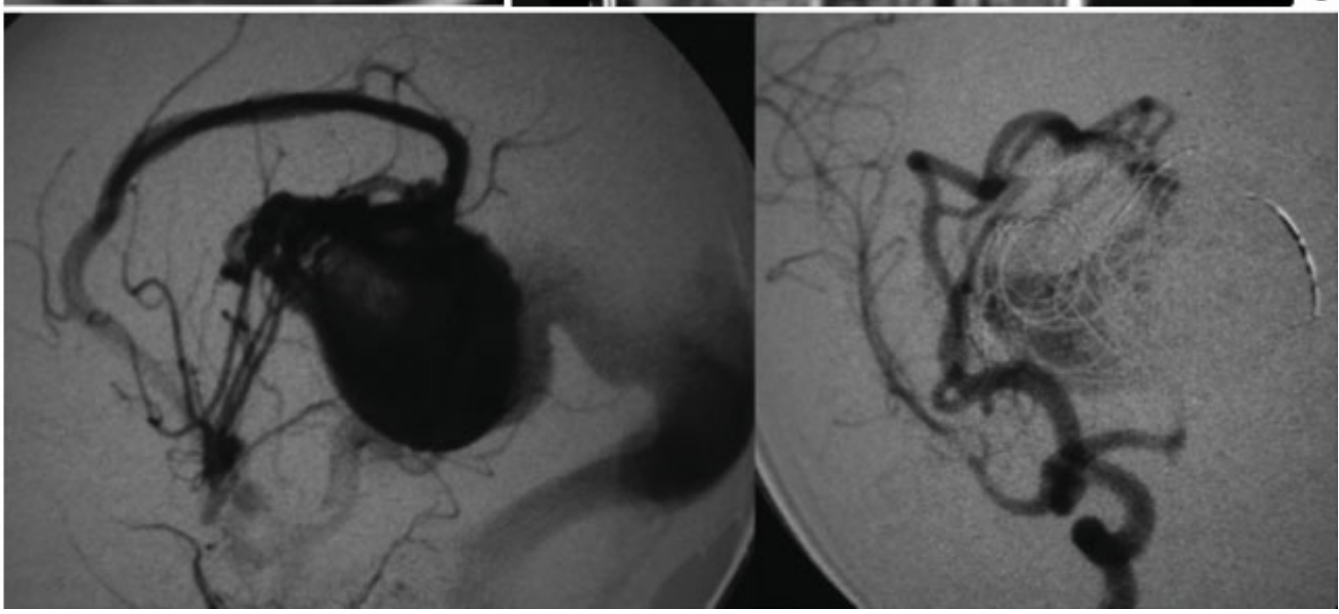

Fig. 1 (A) Two-dimensional ultrasonography in the axial plane based on color and power Doppler ultrasonography at the 28th week of pregnancy, confirming the Galen vein aneurysm. (B) Fetal sagittal T2 magnetic resonance image confirming the Galen vein aneurysm with a hypointense signal (arrow). (C) Postnatal sagittal T2 magnetic resonance image confirming the Galen vein aneurysm (arrow). (D) Angiography performed on the 23rd day after birth. Pre- and post-embolization images, showing reduction in the Galen vein aneurysm.

Despite advancements in prenatal diagnosis, neonatal mortality is high in GVA, with three neonatal deaths (43\%) observed in our case series, as well as a case of serious neurological sequelae in the 4 -year follow-up (14\%). In all these neonatal deaths, the fetuses showed cardiomegaly in the fetal echocardiography. In a case series in which termination of the pregnancy was performed in fetuses with GVA, $89 \%$ of them showed cardiomegaly in the fetal echocardiography. ${ }^{2}$ There are no studies regarding the best fetal echocardiography follow-up in cases with cardiac dysfunction/cardiomegaly. 
Table 2 Findings on magnetic resonance imaging and ultrasonography in our cases of prenatal diagnosis of Galen vein aneurysm

\begin{tabular}{|c|c|c|}
\hline Case \# & Magnetic resonance imaging & Ultrasonography \\
\hline 1 & $\begin{array}{l}\text { Ellipsoid expansive formation, } \sim 2.0 \mathrm{~cm} \text { in its largest } \\
\text { diameter at the level of the middle line in the tentorial } \\
\text { region, posterior to the pituitary, hypointense T1 and T2 } \\
\text { signals, suggesting a flow void, communicating with the } \\
\text { sinus rectus, consistent with aneurysmal dilation of the } \\
\text { Galen vein, with no signs of ventriculomegaly. }\end{array}$ & $\begin{array}{l}\text { An elongated cystic image, measuring } \sim 2.9 \times 1.1 \mathrm{~cm} \text {, } \\
\text { was observed in a location posterior to the thalamus, } \\
\text { continuing on the middle line and spreading superiorly } \\
\text { between the hemispheres. On the color Doppler, a low- } \\
\text { resistance flow was observed, with an arterial } \\
\text { pattern prevailing. The echographic aspect and the flow } \\
\text { pattern are consistent with Galen vein aneurysm. } \\
\text { Enlarged cardiac area and slight pericardial effusion. }\end{array}$ \\
\hline 2 & $\begin{array}{l}\text { Slight ventriculomegaly and expansive ellipsoid forma- } \\
\text { tion in a middle line location, spreading to the posterior } \\
\text { fossa, consistent with arteriovenous malformation } \\
\text { (Galen vein aneurysm). }\end{array}$ & $\begin{array}{l}\text { Slight ventriculomegaly and an elongated anechoic } \\
\text { image in a middle line location, spreading to the pos- } \\
\text { terior fossa. On the color Doppler, an abundant flow of } \\
\text { very low resistance, consistent with an arteriovenous } \\
\text { malformation (Galen vein aneurysm). Enlarged cardiac } \\
\text { area with slight pericardial effusion. }\end{array}$ \\
\hline 3 & $\begin{array}{l}\text { Intracranial ellipsoid expansive formation, } 3.0 \times 2.1 \mathrm{~cm} \\
\text { in size, located on the middle cerebral line }(\text { supraten- } \\
\text { torial), consistent with Galen vein aneurysm. }\end{array}$ & $\begin{array}{l}\text { A homogeneous intracranial cystic area, measuring } 2.2 \\
\times 1.8 \mathrm{~cm} \text {, localized on the middle line (supratentorial). } \\
\text { On color Doppler, intense arteriovenous flow. Normal } \\
\text { heart size and shape. }\end{array}$ \\
\hline 4 & $\begin{array}{l}\text { Ellipsoid expansive formation measuring } 7.0 \times 2.5 \mathrm{~cm} \text {, } \\
\text { supratentorial, slight dilation of the posterior horn of } \\
\text { the brain ventricle and the 3rd ventricle, consistent with } \\
\text { Galen vein aneurysm associated with ventriculomegaly. }\end{array}$ & $\begin{array}{l}\text { A cystic area with a tubular aspect, measuring } 4.1 \times \\
3.7 \mathrm{~cm} \text {, on the middle line (supratentorial), being con- } \\
\text { firmed based on color Doppler as an arteriovenous flow } \\
\text { within, consistent with Galen vein aneurysm. Slight } \\
\text { ventricular dilation. Slightly enlarged cardiac area. } \\
\text { Vascular congestion of the cervical region. }\end{array}$ \\
\hline 5 & $\begin{array}{l}\text { Ventricular dilation and ellipsoid expansive formation, } \\
\text { measuring } \sim 6.0 \times 4.0 \mathrm{~cm} \text {, on the middle line } \\
\text { (supratentorial), consistent with Galen vein aneurysm. }\end{array}$ & $\begin{array}{l}\text { A cystic area with a tubular aspect, measuring } \sim 5.5 \times \\
4.0 \mathrm{~cm} \text {, on the middle line (supratentorial), confirmed } \\
\text { based on color Doppler as an arteriovenous flow within, } \\
\text { consistent with Galen vein aneurysm. Slight ventricular } \\
\text { dilation. }\end{array}$ \\
\hline 6 & $\begin{array}{l}\text { Expansive lesion with lobulated contours and well-de- } \\
\text { fined limits, with a hypointense T2 signal and an iso/ } \\
\text { hypointense T1 signal, measuring } 3.0 \times 1.8 \times 2.3 \mathrm{~cm} \text {, } \\
\text { interhemispheric, posterior to the } 3 \text { rd ventricle, with no } \\
\text { compressive effect. }\end{array}$ & $\begin{array}{l}\text { Anechoic image measuring } 34 \times 28 \mathrm{~mm} \text {, located pos- } \\
\text { teriorly above the thalamus. Slightly dilated lateral } \\
\text { ventricles. Color Doppler with turbulent flow. Normal } \\
3 \text { rd and } 4 \text { th ventricles. }\end{array}$ \\
\hline 7 & $\begin{array}{l}\text { Expansive lesion with lobulated contours and well- } \\
\text { defined limits, with a hypointense T2 signal and an iso/ } \\
\text { hypointense T1 signal, measuring } 3.5 \times 3.4 \times 2.6 \mathrm{~cm} \text {, } \\
\text { interhemispheric, posterior to the } 3 \text { rd ventricle, no } \\
\text { compressive effect. }\end{array}$ & $\begin{array}{l}\text { Anechoic Image measuring } 26 \times 24 \mathrm{~mm} \text {, posterior to } \\
\text { the 3rd ventricle. Normal lateral, } 3 \text { rd, and } 4 \text { th ventricles. } \\
\text { Color Doppler with turbulent flow. }\end{array}$ \\
\hline
\end{tabular}

In a systematic review of 90 cases of prenatal diagnosis of GVA, the mortality rate was $54 \%$, and serious neurological sequelae were found in $14 \%$ of the cases ${ }^{2}$; this was consistent with the findings of our study. Postnatal treatment of GVA will depend on its size; small GVAs with low flow may undergo spontaneous thrombosis, as observed in case \#3. Patients with neurological and cardiac symptoms must be treated by a radiological or surgical intervention. ${ }^{5}$ When GVA is not life threatening, the vascular malformation is best embolized after 5 months from birth, ${ }^{12}$ as performed in cases \#1 and \#7, which showed good postnatal outcomes and normal neurological development in the 4-year follow-up.

In summary, we have presented a series of cases of prenatal diagnosis of GVA based on ultrasonography and MRI. Because GVA is associated with high rates of neonatal death, its prenatal diagnosis is essential for parent counseling and follow-up at tertiary care institutions.

\section{References}

1 Gailloud P, O'Riordan DP, Burger I, et al. Diagnosis and management of vein of galen aneurysmal malformations. J Perinatol 2005;25(08):542-551

2 Deloison B, Chalouhi GE, Sonigo P, et al. Hidden mortality of prenatally diagnosed vein of Galen aneurysmal malformation: retrospective study and review of the literature. Ultrasound Obstet Gynecol 2012;40(06):652-658

3 Gupta AK, Varma DR. Vein of Galen malformations: review. review Neurol India 2004;52(01):43-53

4 Mai R, Rempen A, Kristen P. Prenatal diagnosis and prognosis of a vein of Galen aneurysm assessed by pulsed and color Doppler sonography. Ultrasound Obstet Gynecol 1996;7(03):228-230 
5 Pilu G, Nicolaides KH. Diagnosis of fetal abnormalities: the 18-23-week scan. New York: Parthenon; 1999. Vein of Galen Aneurysm; $14-7$

6 Diebler C, Dulac O, Renier D, Ernest C, Lalande G. Aneurysms of the vein of Galen in infants aged 2 to 15 months. Diagnosis and natural evolution. Neuroradiology 1981;21(04):185-197

7 Wagner MW, Vaught AJ, Poretti A, Blakemore KJ, Huisman TA. Vein of galen aneurysmal malformation: prognostic markers depicted on fetal MRI. Neuroradiol J 2015;28(01):72-75

8 Rios LT, Araujo Júnior E, Nardozza LM, Moron AF, Martins MdaG. Prenatal diagnosis of an aneurysm of the vein of galen by threedimensional power and color Doppler ultrasonography. Clin Med Insights Case Rep 2012;5:77-80
9 Ergenoğlu MA, Yeniel AÖ, Akdemir A, Akercan F, Karadadaş N. Role of 3D power Doppler sonography in early prenatal diagnosis of Galen vein aneurysm. J Turk Ger Gynecol Assoc 2013;14(03):178-181

10 Beucher G, Fossey C, Belloy F, Richter B, Herlicoviez M, Dreyfus M. [Antenatal diagnosis and management of vein of Galen aneurysm: review illustrated by a case report]. J Gynecol Obstet Biol Reprod (Paris) 2005;34(06):613-619 French.

11 Barros FC, Matijasevich A, Maranhão AG, et al. Cesarean sections in Brazil: will they ever stop increasing? Rev Panam Salud Publica 2015;38(03):217-225

12 McSweeney N, Brew S, Bhate S, Cox T, Roebuck DJ, Ganesan V. Management and outcome of vein of Galen malformation. Arch Dis Child 2010;95(11):903-909 